\title{
THE EFFECT OF BLENDED LEARNING MODEL WITH TELEGRAM APPLICATION ON STUDENTS' CRITICAL THINKING ABILITY AND LEARNING OUTCOMES ON SOCIAL STUDIES SUBJECT AT ELEMENTARY SCHOOL
}

\author{
Santi Wahyuningtias ${ }^{1}$, Yatim Riyanto ${ }^{2}$, Rr Nanik Setyowati $^{3}$ \\ 1,2,3 Universitas Negeri Surabaya, Surabaya, Indonesia \\ ${ }^{1}$ santinayya87@gmail.com, ${ }^{2} y a t i m r i y a n t o @ g m a i l . c o m, 3$ naniksetyowati@unesa.ac.id
}

\begin{abstract}
This study aimed to determine the effect of blended learning model with telegram application on students' critical thinking skills and learning outcomes for social studies subjects at fifth grade of SDN Semambung Sidoarjo. The blended learning model with the telegram application was carried out online and offline; this also became a solution due to the covid-19 pandemic so that the learning process could still be carried out. This research was an experimental research with a pretest post test control group design. The subject of this research was the fifth grade students of SDN Semambung Sidoarjo. Data were collected through critical thinking ability test and learning outcomes tests. Furthermore, the data were tested by using validity and reliability tests, while the learning tools were tested by expert validation. Data analysis test was conducted through normality test and homogeneity test. The analytical technique used was t test. The results of this study indicated that (1) there was an effect of blended learning model with telegram application on the students' critical thinking skills at fifth grade elementary school in social studies subject; (2) there was an effect of blended learning model with telegram application on the students' learning outcomes at the fifth grade elementary school in social studies subject. For teachers who faced problems in implementing online learning accompanied by low critical thinking skills and students' learning outcomes, it was recommended to use a blended learning model with telegram application.
\end{abstract}

Keywords: blended learning model, telegram application, critical thinking skills, learning outcomes

\section{PENGARUH MODEL BLENDED LEARNING DENGAN APLIKASI TELEGRAM TERHADAP KEMAMPUAN BERPIKIR KRITIS DAN HASIL BELAJAR MATA PELAJARAN IPS SEKOLAH DASAR}

\begin{abstract}
ABSTRAK
Penelitian ini bertujuan untuk mengetahui pengaruh model blended learning dengan aplikasi telegram terhadap kemampuan berpikir kritis dan hasil belajar mata pelajaran IPS siswa kelas V SDN Semambung Sidoarjo. Model blended learning dengan aplikasi telegram dilaksanakan secara online maupun offline, hal ini juga sebagai bentuk solusi karena adanya pandemi covid-19 sehingga proses pembelajaran tetap dapat terlaksana. Penelitian ini merupakan penelitan eksperimen dengan desain pretest posttest control group design. Subjek penelitian ini adalah siswa kelas V SDN Semambung Sidoarjo. Data dikumpulkan melalui lembar tes kemampuan berpikir kritis dan tes hasil belajar. Selanjutnya diuji menggunakan uji validitas dan uji reliabilitas, sedangkan untuk perangkat pembelajaran diuji oleh validiasi ahli. Persyaratan uji analisis data menggunakan uji normalitas dan uji homogenitas. Teknik analisis yang digunakan adalah uji t. Hasil penelitian ini menunjukkan bahwa (1) ada pengaruh model blended learning dengan aplikasi telegram terhadap kemampuan berpikir kritis siswa kelas V sekolah dasar pada mata pelajaran IPS; (2) ada pengaruh model blended learning dengan aplikasi telegram terhadap hasil belajar siswa kelas V sekolah dasar pada mata pelajaran IPS. Bagi guru yang menghadapi masalah dalam pelaksanaan pembelajaran online disertai dengan rendahnya kemampuan berpikir kritis dan hasil belajar siswa disarankan menggunakan model blended learning dengan aplikasi telegram.
\end{abstract}

Kata Kunci: model blended learning, aplikasi telegram, kemampuan berpikir kritis, hasil belajar

\begin{tabular}{|c|c|c|}
\hline Submitted & Accepted & Published \\
\hline 08 juli 2021 & 07 September 2021 & 17 September 2021 \\
\hline
\end{tabular}

\begin{tabular}{|l|l|c|}
\hline Citation & $:$ & $\begin{array}{r}\text { Wahyuningtias, S., Riyanto, Y., \& Setyowati, R.N. (2021). The Effect of Blended Learning Model with Telegram } \\
\text { Application on Students' Critical Thinking Ability and Learning Outcomes on Social Studies Subject at }\end{array}$ \\
& $\begin{array}{l}\text { Elementary School. Jurnal PAJAR (Pendidikan dan Pengajaran), 5(5), 1397-1414. DOI : } \\
\text { http://dx.doi.org/10.33578/pjr.v5i5.8463. }\end{array}$ \\
\hline
\end{tabular}

\section{PENDAHULUAN}

IPS merupakan satu di antara banyak mata pelajaran yang diajarkan pada jenjang Sekolah Dasar. Menurut Sardjiyo (2014:128) pembelajaran IPS pada jenjang Sekolah Dasar bertujuan membekali siswa dengan ilmu sosial, sikap mental positif, kemampuan berkomunikasi, 
kemampuan memecahkan masalah, serta ilmuilmu sosial yang sesuai dengan pertumbuhan kehidupan masyarakat dan IPTEK yang berguna dalam kehidupannya di masyarakat kelak. Nasution (2015:8) menjelaskan bahwa bahan ajar IPS pada jenjang Sekolah Dasar menggunakan pendekatan terkoordinasi atau kombinasi. Hal tersebut sesuai dengan perkembangan kognitif siswa SD yang berada pada tahap berpikir abstrak. Penjelasan tersebut memiliki arti bahwa bahan ajar IPS yang diajarkan pada jenjang Sekolah Dasar diajarkan secara terpadu sehingga tidak merujuk dari tiap-tiap disiplin ilmu sosial seperti Ekonomi, Sejarah, maupun Geografi.

Permendiknas No. 22 Tahun 2006 cakupan IPS untuk memperoleh kompetensi dasar ilmu pengetahuan dan teknologi serta membudayakan berpikir ilmiah secara kritis, kreatif dan mandiri". Berdasarkan hal itu, pola pengajaran yang disusun guru seharusnya bisa mengkonstruksi pengetahuan peserta didik sehingga bermakna dengan cara melatih kemampuan berpikir kritis siswa untuk menganalisis dan menyelesaikan permasalahan. Dengan dasar itu, seharusnya pelajaran IPS harus diajarkan untuk meningkatkan kemampuan siswa dalam berpikir kritis, rasional, mandiri, dan kreatif, bukan hanya pengetahuan saja (Hestiningsih, 2015). Dengan pembelajaran yang membekali siswa bagaimana cara berpikir maka siswa dapat mengembangkan sendiri kompetensi pengetahuannya dan siswa dapat memecahkan sendiri masalahnya.

Menurut Fisher (2017:10) berpikir kritis adalah "keterampilan untuk menginterpretasi dan mengevaluasi serta aktif mengobservasi, komunikasi, informasi, dan argumentasi". Sedangkan Ahmatika (2017) berpendapat berpikir kritis merupakan kemampuan penalaran ilmiah yang cerdas, independen, jernih, serta rasional. Menurut pendapat di atas dapat ditarik kesimpulan bahwasanya berpikir kritis merupakan kemampuan berpikir rasional dalam menyelesaikan masalah, membuat kesimpulan, bermacam-macam kemungkinan dan memutuskan penyelesaian masalah dengan tepat. Hestiningsih (2015) berpendapat bahwa salah satu cara siswa mendapatkan pengetahuannya sangat bergantung pada cara berpikirnya. Kemampuan berpikir kritis memungkinkan seseorang dapat menyusun pemikiran berdasarkan pengalamannya sehingga dapat mengkaji masalah untuk memecahkan masalah yang terjadi pada dirinya maupun orang lain (Yuadarma, 2017:579).

Belajar menurut Sudjana (2014) adalah proses melihat, mengamati dan memahami sesuatu. Kegiatan pembelajaran melibatkan guru dan siswa, untuk mengoptimalkan capaian tujuan pembelajaran, guru harus menggunakan strategi, pendekatan, model, dan metode yang tepat dalam pembelajarannya. Eggen dan Kauchak (dalam Trianto, 2009:22) menyatakan model pembelajaran memberikan skema serta petunjuk dalam melaksanakan pembelajaran bagi guru. Untuk mencapai keefektivitasan proses belajar guru dapat mengimplementasikan strategi yang sesuai berdasarkan minat dan bakat siswa serta memanfaatkan sumber belajar dan media belajar yang tepat. Pada era globalisasi, perkembangan teknologi menyebabkan perubahan besar di semua bidang kehidupan, termasuk pendidikan (Sulisworo, 2019). Peningkatan kinerja belajar siswa dapat ditingkatkan dengan pemanfaatan kemajuan teknologi saat ini (Ardianti, 2020). Dengan kemajuan teknologi, pembelajaran model blended learning dapat di laksanakan.

Chowdhury (2020) menyatakan bahwa terdapat konsep belajar yang populer di sektor pendidikan saat ini yaitu e-learning yang diimplementasikan melalui blended learning. Model blended learning merupakan program pendidikan formal dimana seorang siswa belajar, sebagian melalui pembelajaran online, dengan beberapa elemen kontrol siswa dari waktu, tempat, jarak, serta antara satu mata pelajaran dengan mata pelajaran lainnya terhubung untuk menciptakan pengalaman belajar yang terintegrasi. Dwiyogo (2018:60) berpendapat bahwa blended learning merupakan model pembelajaran yang menggabungkan pembelajaran secara langsung dengan pembelajaran berbasis teknologi baik online maupun offline. Jadi, blended learning adalah pembelajaran yang menggabungkan antara pembelajaran langsung serta pembelajaran online maupun offline dengan memanfaatkan teknologi 
yang ada serta dengan waktu, tempat yang lebih fleksibel.

Bonk \& Graham (2006) mengidentifikasi 6 alasan berikut untuk menggunakan blended learning meliputi 1) Kekayaan pedagogis, 2) Jalan ke pengetahuan, 3) Hubungan sosial, 4) Agensi pribadi, 5) Efisiensi biaya, dan 6) Kemudahan perbaikan. Pembelajaran menggunakan model blended learning menghasilkan kemampuan untuk menggerakkan siswa ke tingkat pembelajaran yang lebih tinggi, yaitu siswa dapat mempelajari pengetahuan dasar dan penerapannya di rumah, dan mengerjakan lebih banyak proyek kegiatan berbasis di kelas.

Pelaksanaan blended learning haruslah digunakan media yang tepat dan relevan. Online learning merupakan bagian dari pembelajaran model blended learning, di mana dibutuhkan sebuah perangkat keras maupun perangkat lunak untuk mendukung terselenggaranya pembelajaran online (Ansori, 2018). Aplikasi telegram dapat dipilih sebagai salah satu bentuk perangkat lunak, karena aplikasi ini dapat berfungsi sebagai media sosial dan alat komunikasi. Aplikasi telegram dapat memastikan semua siswa mengikuti pembelajaran karena hanya dibutuhkan mempunyai nomor telepon yang dipakai di smartphone dan gabungan fitur telepon dan komputer (Qamar, 2017).

Keunggulan aplikasi Telegram menurut Tio (2019) antara lain: (a) Aplikasinya gratis, (b) Ketika membuka aplikasinya terbebas dari iklan, (c) Data instalasi sangat ringan dan lebih cepat dalam mengirim pesan, (d) Menggunakan sistem end to end sehingga pesan kita lebih aman, (e) Dapat mengirim file dalam kapasitas besar mencapai 1,5 GB, (f) Terdapat fitur channel dengan kapasitas besar, (g) Terdapat fitur bot yang dijalankan di luar kendali manusia, (h) Dapat digunakan pada beberapa jenis perangkat (Smartphone, PC, dan Laptop),(i) Telegram dapat membuat grup obrolan dengan anggota berjumlah 30 ribu orang, (j) Memerlukan ruang penyimpanan yang kecil, (k) Menawarkan fitur stiker gratis, dan (l) Sistem perpesanannya sangat aman. Sedangkan kekurangannya adalah (a) Telegram tidak menyediakan fitur video call, (b) Telegram tidak menyediakan fitur stories.

\begin{abstract}
Berbagai
keunggulan

dari aplikasiTelegram ini diharapkan mampu membuat peserta didik tertarik dengan pembelajaran dan memungkinkan dilakukannya pembelajaran kolaborasi. Peserta didik dapat berinteraksi dan berdiskusi dimanapun dan kapanpun sehingga pembelajaran yang dilakukan lebih bermakna. Hal ini dapat memberikan gambaran bahwa pembelajaran model blended learning merupakan pembelajaran yang menggabungkan antara pembelajaran langsung dan online dengan bantuan teknologi yang berkembang saat ini dalam mencapai tujuan pembelajaran dan diharapkan hasil belajar peserta didik dapat ditingkatkan.
\end{abstract}

Sesuai data tahun lalu dalam mata pelajaran IPS di tetapkan nilai KKMnya 75 akan tetapi dari 18 dari 30 siswa yang mendapatkan nilai di bawah KKM dalam materi tema peristiwa dalam kehidupan dan subtema peristiwa kebangsaan sekitar proklamsi kemerdekaan. Penyebab rendahnya hasil belajar peserta didik adalah anggapan peserta didik tentang pelajaran IPS yang merupakan pelajaran hafalan yang membosankan dan tidak menarik, sehingga siswatidak dapat maksimal dalam pembelajaran.

Berdasarkan wawancara dengan guru kelas $\mathrm{V}$ terdahulu diperoleh data bahwa ketika guru memberikan soal yang berkaitan dengan berpikir kritis siswa kurang dapat mengemukakan pendapatnya, hal ini karena siswa lebih terbiasa dengan soal yang bersifat kognitif tingkat rendah,siswa belum terbiasa mengerjakan soal dengan kemampuan kognitif tingkat tinggi (berpikir kritis), selain itu dalam wawancara guru juga menjelaskan bahwa metode yang digunakan dalam pembelajaran pada tema tersebut adalah penugasan dan ceramah, sehingga siswa merasa bosan karena tidak dilibatkan secara aktif dalam pembelajaran.

Kurikulum 2013 dirancang untuk melibatkan siswa secara aktif dalam pembelajaran dan pembelajaran yang berpusat pada siswa (student center). Kegiatan pembelajaran di buat untuk siswa, bukan siswa yang membuat, jadi disini fungsi guru adalah membuat proses pembelajaran menarik dan bermakna sehingga dapat mengoptimalkan tercainya tujuan 
pembejaran. Untuk itulah, pembuatan kegiatan pembelajaran yang menarik serta bermakna maka siswa tidak mengalami kebosanan dan menjadi tertarik dengan pembelajaran sehingga hasil belajar siswa dapat meningkat.

Berpikir kritis merupakan pemikiran yang bersifat selalu ingin tahu terhadap suatu permasalahan yang ada sehingga terus mencari informasi untuk mencapaisuatu pemahaman yang tepat. Kemampuan berpikir kritis adalah kemampuan yang dapat diasah dan diajarkan kepada peserta didik. Salah satu cara mengembangkan kemampuan berpikir kritis yaitu dengan pembelajaran IPS salah satunya pada materi peristiwa seputar kemerdekaan Indonesia, pada materi ini peserta didik diajarkan untuk memperoleh pengetahuan dengan mengurutkan sejarahdan sebab akibat terjadinya suatu peristiwa serta komunikasi untuk menghasilkan suatu penjelasan yang dapat dipercaya kebenarannya. Namun pada kenyataannya pembelajaran IPS belum banyak yang berorientasi ke arah pembiasaan dan peningkatan kecakapan keterampilan berpikir tingkat tinggi (berpikir kritis) tetapi masih menitik beratkan pada kemampuan kognitif tingkat rendah.

Salah satu model pembelajaran yang mampu menstimulasi dan mengembangkan kemampuan berpikir kritis dan hasil belajar peserta didik adalah model blended learning. Model ini didasarkan atas teori konstruktivisme menurut teori ini peserta didik belajar mengkonstruksi pengetahuannnya melalui interaksi dengan lingkungannya. Berdasarkan paparan permasalahan tersebut, penerapan model blended learning dengan aplikasi telegram diharapkan dapat meningkatkan kemampuan berpikir kritis dan hasil belajar mata pelajaran IPS Kelas V SDN Semambung Sidoarjo.

Tujuan penelitian ini adalah (1) mengetahui adakah pengaruh model blended learning dengan aplikasi telegram terhadap kemampuan berpikir kritis mata pelajaran IPS siswa kelas V SDN Semambung Sidoarjo dan (2) mengetahui adakah pengaruh model blended learning dengan Aplikasi telegram terhadap hasil belajar mata pelajaran IPS siswa kelas V SDN Semambung Sidoarjo

\section{KAJIAN TEORETIS Model Blended Learning dengan Aplikasi
Telegram}

Menurut Zhou (dalam Rusman, 2011:244), blended learning menggunakan pendekatan pembelajaran yang mengkombinasikan antara dua cara online dan pembelajaran langsung pada waktu yang telah ditentukan dan tempat yang berjauhan. Sedangkan Sulisworo (2020) menjelaskan bahwa blended learning ialah cara yang dapat disesuaikan untuk membuat program perencanaan yang membantu pembelajaran yang menggabungkan berbagai kesempatan dan tempat belajar. Bonk dan Graham (2006) menjelaskan bahwa blended learning memfokuskan pada teknologi berbasis komputer dan merupakan campuran dari pembagian pendidikan dan pembelajaran seperti kerangka kerja pembelajaran konvensional dan kerangka kerja penyebaran pembelajaran.

Tujuan utama dari pembelajaran blended learning adalah menciptakan kemandirian, keberlanjutan pembelajaran sepanjang hayat dan perkembangan peserta didik sesuai dengan karakteristiknya (Dwiyogo, 2018:60). Dalam mengatasi masalah dalam proses pembelajaran pendidik dan siswa dimudahkan dengan penerapan model blended learning untuk memeroleh pemahaman dari berbagai cabang ilmu untuk dapatmelakukan pembelajaran yang optimal menggunakan teknologi yang lebih fleksibel.

Dalam pelaksanaan pembelajaran menggunakan model blended learning dengan aplikasi Telegram ini, karena guru dan siswa belum pernh menerapkannya jadi komposisinya $50 \%$ tatap muka, $25 \%$ pembelajaran secara mandiri, $25 \%$ pembelajaran dengan menggunakan web (Sudarman, 2018). Dengan adanya komunikasi yang efektif serta interaksi yang maksimal antara pendidik dan peserta didik dan kemandirian serta kreativitas siswa untuk mencari sumber belajar melalui web maka dapat menunjang keberhasilan penggunaan model blended learning ini.

Model pembelajaran pada blended learning yang digunakan untuk lebih spesifiknya yaitu model campuran (hybrid learning), di mana model ini langsung dikaitkan dengan web di dalam jaringan (Suhartono, 2016). Blended Learning 
yang dilaksanakan di dalam jaringan dapat diakses berdasarkan perjanjian antara pendidik dan peserta didik. Blended learning adalah pembelajaran yang mengkombinasikan pembelajaran langsung dan pembelajaran berbasis online. Kegiatan belajar dan mengajar secara langsung dilakukan saat siswa berada di kelas, sedangkan kegiatan belajar mengajar online dilaksanakan di luar kelas dengan menggunakan aplikasi telegram. tujuan dari pembelajaran blended learning adalah siswa lebih banyak menggunakan sumber belajar yang lebih bervariasi, sedangan Telegram di gunakan agar siswa lebih tertarik dalam pembelajaran.

Untuk membangun lingkungan yang kolaboratif dapat digunakan fitur yang tersedia dalam aplikasi Telegram antara lain Replay, Mention, dan Hastag (Qamar, 2018). Aplikasi Telegram dapat digunakan dan diakses dengan mudah sehingga pembelajaran online tidak hanya sebagai sarana untuk memberikan tugas dan materi tambahan tetapi siswa juga dapat berdiskusi untuk menunjang pembelajaran tatap muka sehingga lebih berkualitas. Dengan demikian peserta didik dapat merasakan pengalaman baru melalui pembelajaran dan menentukan cara sendiri dalam belajar dengan menggunakan telegram. Berdasarkan hasil penelitian Qamar \& Riyadi (2018) dengan judul Efektivitas Blended Learning menggunakan Aplikasi Telegram menunjukkan bahwa partisipan sesi online lebih aktif dari sesi offline. Di mana peningkatan motivasi dengan nilai 85.63, keberanian mengungkap ide dan bertanya dengan nilai 80.63 , peningkatan pengetahuan nilaiya 80.63 , mengasyikan dengan nilai 76.25 , daya ingat nilainya 78.13 , keterbukaan untuk bertukar pikiran 86.88, dan dorongan untuk berpikir nilainya sebesar 82,63. Penguasaaan materi pun menalami peningkatan dengan nilai rtarata akhir 74.85 dan simpangan baku 13.15.

\section{Kemampuan Berpikir Kritis}

Pembelajaran yang dilaksanakan pengajar harus menyertakan kemampuan berpikir kritis siswa, yang merupakan salah satu kemampuan yang harus dimiliki siswa yang menyangkut dengan penanganan masalah sehari-hari. Menurut Ornstein \& Levine (Widodo, 2016) hari ini kita berbicara tentang penalaran dasar dan kecakapan berpikir untuk menunjukkan kemampuan berpikir kritis. Mayoritas dari usaha negara untuk meningkatkan keterampilan berpikir kritis siswa.

Menurut Ennis (dalam Yuadarma, 2017, p.14) terdapat 12 Indikator kemampuan berpikir kritis yang disederhanakan menjadi 5 Indikator yang terbagi menjadi subindikator sebagai berikut: menyampaikan penjelasan secara sederhana; (1) memfokuskan pertanyaan, (2) menganalisis argument, (3) bertanya dan menjawab pertanyaan. Mengkonstruksi kemampuan dasar; (4) mempertimbangkan dan menggunakan keabsahan sumber, (5) mengobservasi dan mempertimbangkan hasil observasi. Membuat kesimpulan; (6) membuat deduksi dan mempertimbangkan hasil observasi, (7) membuat induksi dan mempertimbangkan hasil induksi, (8) membuat dan mempertimbangakan nilai keputusan. Menjelaskan secara lanjut; (9) memdefinisikan istilah, mempertimbangkan definisi, (10) mengidentifikasi suatu tindakan. Membuat stategi dan taktik; (11) memutuskan suatu tindakan, (12) berinteraksi dengan orang lain.

Pada penelitian ini mengambil 5 fokus Indikator untuk penelitian ini yaitu; (1) kemampuan bertanya, (2) kemampuan menjawab pertanyaan, (3) mampu membuat argumen, (4) mampu memecahkan masalah, dan (5) kemampuan menyimpulkan.

\section{Hasil Belajar}

Menurut Maisaroh dan Rostrieningsih (2010) belajar merupakan proses memberikan stimulus yang dapat memberikan perubahan terhadap peserta didik baik itu pengetahuan maupun tingkah lakunya setelah mendapatkan pembelajaran. Sedangkan menurut Sudjana (2014) belajar merupakan suatu siklus yang dapat menyebabkan perubahan pada diri seseorang. Dari pernyataan di atas dapat disimpulkan bahwa belajar merupakan suatu siklus yang merubah diri seseorang dari tidak mampu menjadi mampu, dari tidak tahu menjadi mengetahui, dan menyangkut semua ranah dalam diri siswa baik pengetahuan, sikap dan psikomotor.

Melalui proses belajar, siswa mengalami perubahan pada dirinya melalui stimulus yang diberikan itu dinamakan hasil belajar. Perubahan 
kemampuan, keterampilan, dan sikapyang terjadi akibat dari suatu kegiatan belajar mengajar merupakan hasil belajar (Maisaroh dan Rostrieningsih, 2010). Jadi hasil belajar adalah hasil atau berubahan yang terjadi dalam diri peserta didik yang di dapatkan dari evaluasi selama proses belajar mengajar. Hasil belajar merupakan perubahan tingkah laku baik wawasan, pengertian, cara pandang dan kemampuan siswa sehingga menjadi lebih baik. Keberhasilan dalam belajar mencerminkan prestasi belajar seseorang selama kegiatan pembelajaran dalam bentuk nilai yang diukur melalui evaluasi.

\section{METODE PENELITIAN}

Penelitian ini merupakan penelitian kuantitatif yaitu penelitian yang analisisnya berupa data angka yang menggunakan metode statistik dalam pengolahannya yang digunakan sebagai cara untuk menarik kesimpulan pada suatu hasil penelitian. Arikunto (2013) menjelaskan bahwa penelitian kuantitatif merupakan penelitian yang menggunakan angka dalam proses pengumpulan, penafsiran serta hasil dari penelitian tersebut. Jenis penelitian yang dilakukan adalah quasi experimental research. Riyanto (2007, p.120) menjelaskan bahwa penelitian eksperimen merupakan penelitian yang melakukan kontrol pada kondisi tertentu dan dilakukan secara sistematis, logis, dan teliti. Jadi, dalam penelitian eksperimen ini terdapat keterkaitan antara sebab dan akibat. Penelitian eksperimen dilakukan dengan cara memberikan treatment tertentu di kelas eksperimen, dan terdapat pembanding dari kelas kontrol yang dipilih terhadap perlakuan apa yang akan diberikan kepada kelas tersebut

Peneliti menggunakan desain penelitian yaitu desain pre-test dan post-test control group design. Berdasarkan desain ini, penelitian eksperimen biasanya dibagi menjadi dua kelompok yaitu kelompok ekperimen dan kelompok kontrol. Riyanto (2007:121) menjelaskan, Kelompok eksperimen adalah kelompok yang diberikan perlakuan atau treatment, sedangkan kelompok kontrol tidak diberikan perlakuan apa-apa. Treatment atau perlakuan yang diberikan pada kelompok eksperimen yaitu dengan menggunakan model blended learning dengan aplikasi Telegram, sedangkan kelompok kontrol melaksanakan pembelajaran dengan menggunakan meode ceramah dan penugasan tanpa menggunakan model Blended Learning. Kelompok kontrol digunakan untuk membandingkan perubahan yang terjadi setelah diberi perlakuan yang diberikan pada kelompok eksperimen dalam pembelajaran dengan menggunakan model Blended Learning dengan aplikasi Telegram. Adapun rancangan penelitian seperti yang dikemukakan oleh Sugiyono (2011:76) adalah seperti pada tabel di bawah ini

Tabel 1. Rancangan Penelitian Pretest-Posttest Control Group Design

\begin{tabular}{lccc}
\hline Kelompok & Pretest & Variabel Perlakuan & Posttest \\
\hline Eksperimen & $\mathrm{O} 1$ & $\mathrm{X}$ & $\mathrm{O} 2$ \\
Kontrol & $\mathrm{O} 3$ & $\mathrm{C}$ & $\mathrm{O} 4$ \\
\hline
\end{tabular}

Keterangan:

O1 : Hasil Pretest pada kelompok perlakuan

O2 : Hasil Posttest pada kelompok perlakuan

O3 : Hasil Pretest pada kelompok kontrol

O4 : Hasil Posttest pada kelompok kontrol

$\mathrm{X}$ : Perlakuan (treatmen) model blended

learning pada kelompok perlakuan

C : Perlakuan pada kelompok kontrol
Subjek dari penelitian eksperimen adalah siwa kelas 5 SDN Semambung Kabupaten SIdoarjo yang berjumlah 30 siswa. Waktu penelitian dilakukan di semester genap, dari awal Januari samapi Maret 2021.

Data penelitian dikumpulkan melalui teknik tes melalui intrumen lembar tes berpikir kritis dan lembar tes hasil belajar siswa. Tes ini berjumlah 5 butir soal uraian. Soal tes sebelum digunakan untuk penelitian dilakukan uji coba 
instrumen untuk mengetahui tingkat validitas dan reliabilitas suatu instrumen. Uji validitas menggunakan rumus korelasi product moment dan uji reliabilitas dianalisis menggunakan alpha cronbach.

Teknik analisis data menggunakan analisis uji $\mathrm{t}$ independent sampel t-test taraf signifikansi 5\%. Sebelum dilakukan uji hipotesis dilakukan terlebih dahulu uji asumsi yang meliputi uji normalitas menggunakan rumus shapiro-wilk dan uji homogenitas menggunakan levene test.

\section{HASIL DAN PEMBAHASAN}

Sebelum peneliti melakukan penelitian di lapangan, maka terlebih dahulu dilakukan validasi perangkat dan instrumen penelitian oleh Validator Ahli di bidangnya. Komponen perangkat pembelajaran yang diuji validasikan meliputi Rencana Pelaksanaan Pembelajaran (RPP), Materi Pembelajaran, Lembar Kegiatan Peserta Diidik (LKPD), lembar tes berpikir kritis dan tes hasil belajar. Berikut hasil validasi Ahli dijelaskan pada tabel di bawah ini.

Tabel 2. Hasil Validasi oleh Validator Ahli

\begin{tabular}{llllll}
\hline No. & $\quad$ Instrumen yang divalidiasi & V1 & $\begin{array}{c}\text { V2 } \\
\text { V2or }\end{array}$ & $\begin{array}{l}\text { Rata- } \\
\text { Rata }\end{array}$ & Predikat \\
\hline 1. & Rencana Pelaksanaan Pembelajaran & 3.4 & 3.1 & 3.3 & Baik \\
2. & Materi Pembelajaran & 3.7 & 3.2 & 3.3 & Baik \\
3 & Lembar Kerja Peserta Didik & 3.8 & 3.3 & 3.6 & Baik sekali \\
4. & Tes Hasil Belajar & 3.6 & 3.2 & 3.4 & Baik \\
5. & Tes Kemampuan Berpikir Kritis & 3.5 & 3.3 & 3.4 & Baik \\
\hline
\end{tabular}

Keterangan : V1 = Validator Ahli 1; V2 = Validator Ahli 2

Berdasarkan tabel di atas, dapat dinyatakan bahwa keseluruhan instrumen penelitian yang diuji validasikan oleh validator Ahli di bidangnya dinyatakan baik unuk digunakan dalam penelitian. Selain itu, lembar tes yang digunakan dalam penelitian dilakukan uji coba instrumen terlebih dahulu pada sekolah dasar lainnya.

Uji coba instrumen dilakukan untuk mengetahui kelayakan suatu instrumen penelitian. Untuk itulah dilakukan uji validitas dan uji reliabilitas. Analisis validitas tiap butir instrumen menggunakan rumus pearson atau product moment, sedangkan analisis reliabilitas menggunakan rumus Cronbach's Alpha untuk instrumen berpikir kritis dan hasil belajar siswa karena menggunakan skor berbentuk skala. (Sundayana, 2014:69; Siregar, 2014:89). Instrumen penelitian berupa tes berpikir kritis siswa dikatakan valid jika nilai rhitung> rtabel (Sugiyono, 2016:185). Adapun ketentuan rtabel sig. (two-tailed) untuk jumlah data $\mathrm{n}=15$ adalah 0,514

Tabel 3. Hasil Uji Validitas Tes Berpikir Kritis Siswa

\begin{tabular}{cccc}
\hline Item & r Hitung & $\begin{array}{c}\text { r } \\
\text { Tabel }\end{array}$ & Keterangan \\
\hline Butir 1 & 0,859 & 0,514 & Valid \\
Butir 2 & 0,603 & 0,514 & Valid \\
Butir 3 & 0,741 & 0,514 & Valid \\
Butir 4 & 0,699 & 0,514 & Valid \\
Butir 5 & 0,640 & 0,514 & Valid \\
\hline
\end{tabular}


Tabel 4. Hasil Uji Validitas Tes Hasil Belajar

\begin{tabular}{lccc}
\hline Item & r Hitung & $\begin{array}{c}\mathbf{r} \\
\text { Tabel }\end{array}$ & Keterangan \\
\hline Butir 1 & 0.709 & 0.514 & Valid \\
Butir 2 & 0.665 & 0.514 & Valid \\
Butir 3 & 0.652 & 0.514 & Valid \\
Butir 4 & 0.668 & 0.514 & Valid \\
Butir 5 & 0.704 & 0.514 & Valid \\
\hline
\end{tabular}

Berdasarkan hasil uji validitas tes berpikir kritis dan tes hasil belajar, semua butir tes pada dua variabel tersebut nilai $r_{\text {hitung }}>r_{\text {tabel }}$, sehingga dapat dikatakan bahwa keseluruhan butir tes dalam kategori valid dan dapat digunakan sebagai instrumen pengumpulan data untuk variabel kreativitas belajar siswa.

Setelah uji validitas instrumen penelitian dilakukan, langkah selanjutnya peneliti melakukan uji reliabilitas. Hal ini untuk mengetahui apakah instrumen tes sudah reliabel atau belum. Pengujian reliabilias dalam instrumen penelitian yang telah dipercaya dan reliabel akan menghasilkan data yang dapat dipercaya juga. Pada penelitian ini dilakukan uji reliabilitas untuk menguji instrumen lembar tes kemampuan berpikir kritis dan tes hasil belajar dengan menggunakan alpha cronbach's melalui program pengolah data SPSS. Kriteria penentuan batas reliabilitas adalah 0.6 (Sundayana, 2014:70). Adapun hasil reliabilitas tes berpikir kritis dan tes hasil belajar sebagai berikut

Tabel 5. Hasil Uji Reliabilitas Tes Berpikir Kritis

\begin{tabular}{ll}
\hline Cronbach's Alpha & N of Items \\
\hline .0741 & 5 \\
\hline
\end{tabular}

Tabel 6. Hasil Uji Reliabilitas Tes Hasil Belajar

\begin{tabular}{ll}
\hline Cronbach's Alpha & N of Items \\
\hline .795 & 5 \\
\hline
\end{tabular}

Berdasarkan tabel klarifikasi koefisien reliabilitas (Sundayana, 2014:12) diketahui bahwa hasil uji reliabilitas instrumen tes berpikir kritis dan tes hasil belajar memiliki tingkat reliabel tinggi karena berada pada kriteria $60 \leq \mathrm{r}_{\mathrm{xy}} \leq 0.80$ sehingga instrumen ini dapat digunakan dalam penelitian.

Selanjutnya, peneliti melakukan pretest kemampuan berpikir kritis dan hasil belajar pada kelas eksperimen maupun kelas kontrol. Pretest kemampuan berpikir kritis siswa dilakukan dengan tes untuk mengetahui kemampuan berpikir siswa sebelum diberikan treatment model blended learning dengan aplikasi Telegram. Pretest hasil belajar siswa bertujuan mengetahui hasil belajar siswa materi Peristiwa Seputar Proklamasi Kemerdekaan Indonesia sebelum pembelajaran menggunakan model Blended Learning dengan aplikasi telegram.
Pemberian perlakuan pada kelas ekperimen maupun pembelajaran pada kelas kontrol dilaksanakan secara dilakukan secara tatap muka. Sementara model Blended Learning dengan aplikasi Telegram digunakan pada kelas eksperimen. Jadi kelas eksperimen melakukan pembelajaran secara daring dan luring, pembelajaran daring menggunakan aplikasi telegram sedangkan pembelajaran luring dengan pembelajaran tatap muka.

Pembelajaran kelas eksperimen yang menggunakan model Blended Learning dengan aplikasi Telegram dilaksanakan pada tanggal 5 April dan 6 April 2021. Setelah perlakuan diberikan, selanjutnya siswa mengerjakan posttest untuk mengetahui kemampuan berpikir kritis dan hasil belajar siswa pada materi Peristiwa Seputar Proklamasi Kemerdekaan Indonesia sebelum 
pembelajaran menggunakan model Blended Learning dengan aplikasi telegram.

Pembelajaran kelas kontrol dilakukan pada tanggal 7 April dan 8 April 2021 dengan menggunakan model pembelajaran konvensional yang biasa digunakan oleh guru di kelas tersebut yaitu ceramah dan penugasan. Pada akhir pembelajaran selanjutnya diberikan posttest untuk mengetahui kemampuan berpikir kritis dan hasil belajar siswa.

Tabel 7. Hasil Analisis Data Berpikir Kritis Siswa

\begin{tabular}{llll}
\hline \multirow{2}{*}{ Kelas } & Tes & \multicolumn{2}{c}{ Persentase (\%) } \\
\cline { 3 - 4 } & & Tuntas & Belum \\
& Pretest & 20 & 80 \\
Eksperimen & Posttest & 86.7 & 13.3 \\
& Pretest & 20 & 80 \\
Kontrol & Posttest & 60 & 40 \\
\hline
\end{tabular}

Hasil analisis peningkatan berpikir kritis siswa kelas eksperimen yang belajar menggunakan model blended learningmelalui aplikasi telegramdihitung dengan rumus normalized gain adalah 0.64 , atau meningkat sebesar $64 \%$. Artinya dalam klasifikasi gain score terjadi peningkatan sedang. Sementara itu, peningkatan berpikir kritis siswa di kelas kontrol menggunakan model pembelajaran konvensional dihitung dengan rumus normalized gainadalah 0.38 , atau meningkat sebesar 38\% dalam klasifikasi gain score artinya terjadi peningkatan dengan klasifikasi sedang

Tabel 8. Hasil Analisis Data Hasil Belajar

\begin{tabular}{cccc}
\hline \multirow{2}{*}{ Kelas } & \multirow{2}{*}{ Tes } & \multicolumn{2}{c}{ Persentase (\%) } \\
\cline { 3 - 4 } & Pretest & Tuntas & Belum Tuntas \\
\hline \multirow{2}{*}{ Eksperimen } & Posttest & 93.3 & 86.7 \\
\multirow{2}{*}{ Kontrol } & Pretest & 13.3 & 6.6 \\
& Posttest & 60 & 86.7 \\
& &
\end{tabular}

Hasil analisis peningkatan hasil belajar siswa kelas eksperimen yang belajar menggunakan model Blended Learning melalui aplikasi telegram ihitung dengan rumus normalized gain adalah 0.67, atau meningkat sebesar 67\%. Artinya dalam klasifikasi gain score terjadi peningkatan sedang. Sementara itu, peningkatan berpikir kritis siswa di kelas kontrol menggunakan model pembelajaran konvensional dihitung dengan rumus normalized gain adalah 0.48, atau meningkat sebesar $48 \%$ dalam klasifikasi gain score artinya terjadi peningkatan dengan klasifikasi sedang.
Uji normalitas bertujuan agar diketahui normalttidaknya distribusi data yang digunakan dalamppenelitian. Data penelitian ini adalah hasil tes berpikir kritis dan tes hasil belajar siswa. Uji normalitas yang digunakan dalam penelitian ini adalah uji Saphiro-Wilk. Distribusi data dikatakan normal jika hasil signifikansi lebih dari 0.05 (Sundayana, 2014:88). Hasil uji normalitas berpikir kritis dan tes hasil belajar siswa sebagai berikut. 
Tabel 9. Hasil Uji Normalitas

\begin{tabular}{|c|c|c|c|c|c|}
\hline \multicolumn{2}{|c|}{ Kelompok } & Kelompok & $\begin{array}{c}\text { Nilai } \\
\text { Signifikansi }\end{array}$ & Taraf & Keterangan \\
\hline $\begin{array}{l}\text { Berpikir } \\
\text { (pretest) }\end{array}$ & Kritis & \multirow{2}{*}{ Ekseprimen } & 0.539 & 0.05 & Normal \\
\hline $\begin{array}{l}\text { Berpikir } \\
\text { (posttest) }\end{array}$ & Kritis & & 0.487 & 0.05 & Normal \\
\hline $\begin{array}{l}\text { Berpikir } \\
\text { (pretest) }\end{array}$ & Kritis & \multirow{2}{*}{ Kontrol } & 0.460 & 0.05 & Normal \\
\hline $\begin{array}{l}\text { Berpikir } \\
\text { (posttest) }\end{array}$ & Kritis & & 0.853 & 0.05 & Normal \\
\hline \multicolumn{2}{|c|}{ Hasil belajar (pretest) } & \multirow[b]{2}{*}{ Ekseprimen } & 0.487 & 0.05 & Normal \\
\hline $\begin{array}{l}\text { Hasil } \\
\text { (posttest) }\end{array}$ & belajar & & 0.670 & 0.05 & Normal \\
\hline \multicolumn{2}{|c|}{ Hasil belajar (pretest) } & \multirow[t]{2}{*}{ Kontrol } & 0.952 & 0.05 & Normal \\
\hline $\begin{array}{l}\text { Hasil } \\
\text { (posttest) }\end{array}$ & belajar & & 0.549 & 0.05 & Normal \\
\hline
\end{tabular}

Uji normalitas dengan menggunakan rumus shapiro-wilk dengan taraf signifikansi $5 \%$ yaitu 0.05 . Jika nilai signifikansi $<0.05$ kesimpulannya data tidak berditrubusi normal. Namun jika nilai signifikan > 0.05 maka data tersebut berdistribusi normal. Berdasarkan tabel 9 di atas bahwa semua variabel memiliki nilai lebih dari 0.05 , sehingga dapat dinyatakan bahwa semua variabel penelitian berditribusi normal.
Uji homogenitas ini dilakukan untuk menguji kesamaan dari beberapa bagaian sampel. Uji homogenitas data tersebut dihitung dengan menggunakan uji levene test dengan kriteria apabila probalitas $(\mathrm{P}>0.05)$ maka sampel bersifat homogen, sedangkan apabila probalittas $(\mathrm{P}<0.05)$ maka sampel bersifat tidak homogen. Berikut hasil uji homogenitas.

Tabel 10. Hasil Uji Homogenitas

\begin{tabular}{lccc}
\hline \multicolumn{1}{c}{ Variabel } & $\begin{array}{c}\text { Nilai } \\
\text { Signifikansi }\end{array}$ & Taraf & Keterangan \\
\hline Berpikir Kritis (Pretest) & 0.883 & 0.05 & Homogen \\
Berpikir Kritis (Posttest) & 0.496 & 0.05 & Homogen \\
Hasil Belajar (Pretest) & 0.983 & 0.05 & Homogen \\
Hasil Belajar (Posttest) & 0.901 & 0.05 & Homogen \\
\hline
\end{tabular}

Tabel 10 merupakan data uji homogenitas dengan menggunakan taraf signifikansi $5 \%$ yaitu 0.05. Pengambilan kesimpulannya, jika nilai signifikansi $<0.05$ maka varian kelompok data tidak homogen, dan jika nilai signifikansi $>0.05$ maka varian kelompok data adalah homogen. Berdasarkan tabel diatas, keseluruhan variabel memiliki varian data homogen
Uji hipotesis guna menjawab rumusan masalah dan hipotesis yang diajukan dalam penelitian ini. Uji hipotesis yang digunakan dalam penelitian ini adalah menggunakan uji $t$ menggunakan rumus independent sampel t-test. Uji $\mathrm{t}$ diperlukan untuk melakukan pengujian tingkat signifikansi antar tiap pengaruh variabel independen kepada variabel dependen secara parsial. 
Tabel 11. Pengujian hipotesis

\begin{tabular}{ccccc}
\hline Variabel & T & Df & Sig. (2-tailed) & Deskripsi \\
\hline Berpikir Kritis & 2.822 & 28 & 0.009 & Terdapat pengaruh yang signifikan \\
Hasil Belajar & 2.508 & 28 & 0.018 & Terdapat pengaruh yang signifikan \\
\hline
\end{tabular}

Nilai $t_{\text {tabel }}$ pada (df.28) signifikansi 0.05 sebesar 1.701 (Priyatno, 2016:142). Berdasarkan tabel di atas, dinyatakan bahwa kemampuan berpikir kritis siswa memperoleh nilai sig 2 tailed sebesar $0.009<\alpha(0.05)$ dengan $t_{\text {hitung }}>t_{\text {tabel }}$ sebesar $(2.822>1.701)$, maka dapat dinyatakan bahwa terdapat pengaruh yang signifikan penggunaan model blended learning dengan aplikasi telegram terhadap kemamuan berpikir kritis siswa kelas V Sekolah Dasar.

Analisis pengujian hipotesis pada hasil belajar siswa memperoleh nilai sig 2 tailed sebesar $0.018<\alpha(0.05)$ dengan $t_{\text {hitung }}>\mathrm{t}_{\text {tabel }}$ sebesar $(2.508>1.701)$, maka dapat dinyatakan bahwa terdapat pengaruh yang signifikan penggunaan model blended learning dengan aplikasi telegram terhadap hasil belajar siswa kelas V sekolah dasar.

Ennis (1985) mengungkapkan ada 6 komponen fundamental dalam berpikir kritis yaitu: (1) center, (2) reason, (3) conclusion, (4) keadaan, (5) kejelasan, (6) pemeriksaan secara menyeluruh. Indikator berpikir kritis yang digunakan penulis antara lain; (1) kemampuan dalam bertanya, (2) kemampuan dalam menjawab pertanyaan, (3) kemampuan dalam mengungkapkan pendapat, (4) kemampuan memecahkan masalah, dan (5) membuat kesimpulan. Tes kemampuan berpikir kritis ini bertujuan untuk mengukur kemampuan berpikir kritis siswa dengan soal berbentuk uraian sebanyak 5 soal. Pemberian tes dilakukan sebanyak dua kali yang pertama saat pretest dan yang kedua pada saat posttest.

Adanya pengaruh model pembelajaran blended learning dengan aplikasi telegram terhadap kemampuan berpikir siswa di kelas eksperimen sejalan dengan pendapat Dwiyogo (2018:60) bahwa blended learning adalah model pembelajaran perpaduan antara pembelajaran dengan menggunakan teknologi dan pembelajaan secara langsung yang bertujuan untuk menciptakan kemandirian yang sesuai dengan karakteristik peserta didik. Pendapat lain yang mendukung terkait dengan model pembelajaran blended learning dikemukakan oleh Pratiwi (2019:2) bahwa Model pembelajaran blended learning dapat digunakan sebagai model pembelajaran alternative yang dapat mebuat siswa bepikir secara kreatif dan kritis, yang dapat memaksimalkan interaksi antara guru dan siswa.

Berpikir kritis adalah proses intelektual disiplin secara aktif dan terampil konseptualisasi, menerapkan, menganalisis, mensintesis, dan / atau mengevaluasi informasi yang dikumpulkan dari, atau dihasilkan oleh, observasi, pengalaman, refleksi, penalaran, atau komunikasi, sebagai panduan untuk keyakinan dan tindakan. Berfikir kritis merupakan kemampuan memecahkan masalah dengan menggabungkan pengetahuan dalam sistem kognitif anak, sehingga dapat memilih solusi yang tepat (Cahyono, 2017). Kemampuan berfikir kritis sangat penting untuk dikembangkan karena peserta didik lebih mudah dalam menganalisis dan membuat argument yang kuat untuk membenarkan setiap keputusan berdasarkan bukti yang didapatkan dan hasil evaluasi yang dilakukan.

Berpikir kritis memiliki peranan yang penting dalam dunia pendidikan dan merupakan tujuan utama dalam pembelajaran (Lakovos, 2011). Indikator berpikir kritis yang diungkapkan meliputi memfokuskan pertanyaan, menganalisis argumen, mempertimbangkan apakah sumber dapat dipercaya atau tidak, mengidentifikasi asumi-asumsi dan menentukan tindakan. Solikh, et al., (2018) mengungkapkan bahwa pendidikan abad 21 harus mampu membangun peserta didik yang berpengetahuan sehingga memiliki kemampuan berpikir kritis (critical thinking). Kemampuan ini hendaknya dilatihkan kepada siswa dalam mata pelajaran IPS. Pengukuran kemampuan berpikir kritis dapat dilakukan dengan membangun berbagai kemungkinan tanggapan serta pilihan alternatif untuk memecahkan masalah 
Pembelajaran IPS diarahkan pada penguasaan kompetensi bukan hanya dalam pengetahuan saja tetapi juga dalam budaya berpikir ilmiah yang kritis, kreatif dan mandiri (Hestiningsih \& Sugiharsono, 2015). Hal ini yang sering kurang diperhatikan oleh guru yaitu membekali peserta didik dengan budaya berpikir ilmiah tersebut. Guru sering hanya terfokus pada penguasaan kompetensi dasar ilmu pengetahuan semata dan tidak mengajarkan cara berpikir. Padahal, dengan memberikan bekal kompetensi berpikir ilmiah secara kritis, kreatif dan mandiri, peserta didik dapat memperoleh dan mengembangkan ilmu pengetahuan dengan usahanya sendiri. Pada umumnya, pembelajaran yang dilaksanakan masih bersifat teacher centered dan bukan student centered. Hal ini disebabkan karena guru seringkali kurang mempersiapkan diri di dalam melaksanakan pembelajaran. Tanpa perencanaan dan persiapan yang matang guru melaksanakan pembelajaran.

Penelitian ini dilaksanakan pada masa pandemi virus corona. Pedoman penyelanggaraan belajar dirumah dikeluarkan pemerintah pada surat edaran Kemendikbud nomer 04 tahun 2020 untuk mencegah penyebaran virus corona, maka kegiatan belajar mengajar secara tatap muka dihentikan dan diganti pembelajaran secara daring (Baety \& Munandar, 2021). Maka dari itu, model blended learning dapat menjadi solusi agar pembelajaran tetap dapat terlaksana serta dapat meningkatkan kemampuan berpikir kritis siswa. Penerapan model pembelajaran blended learning memiliki tingkat fleksibilitas yang tinggi, seperti dapat dengan mudah menyesuaikan waktu yang dimiliki guru dan siswa (Wahyunita \& Subroto, 2021)

Blended learning adalah pembelajaran yang mengkombinasikan pembelajaran langsung dan pembelajaran berbasis online. Kegiatan belajar dan mengajar secara langsung dilakukan saat siswa berada di kelas, sedangkan kegiatan belajar mengajar online dilaksanakan di luar kelas dengan menggunakan aplikasi telegram. Tujuan dari pembelajaran blended learning adalah siswa lebih banyak menggunakan sumber belajar yang lebih bervariasi, sedangkan Telegram digunakan agar siswa lebih tertarik dalam pembelajaran. Selain itu, model blended learning yang diterapkan oleh guru memiliki beberapa kelebihan. Kelebihan tersebut seperti pembelajaran daring dapat membantu siswa untuk dapat belajar secara mandiri tanpa bimbingan guru secara langsung, membantu pembelajaran konvensional yang sering dilakukan guru sehingga membantu siswa memperoleh informasi tanpa harus bertatap muka dengan guru (Anggraini, et al., 2016), meningkatkan rasa ingin tahu siswa terhadap suatu informasi, pembelajaran yang fleksibel, dan dapat mengurangi biaya yang digunakan dalam proses pembelajaran pada umumnya. Selain itu, siswa dapat belajar sesuai dengan kecepatan belajarnya masing-masing tanpa dipengaruhi oleh temannya (Yapici and Akbayin, 2012)

Penggunaan model blended learning dengan aplikasi telegram dapat meningkatkan keterampilan berpikir kritis. Sebelum materi dijelaskan lebih detail oleh guru, peserta didik terlebih dahulu mengerjakan kegiatan seperti menelaah dan memahami materi yang diberikan guru sesuai dengan teori konstruktivisme, agar peserta didik dapat membuat pengetahuan dan pemaknaannya sendiri terlebih dahulu. Kemudian guru membimbing dan mengarahkan siswa secara melalui kegiatan diskusi. Seusai melakukan kegiatan diskusi, siswa diarahkan untuk menjawab pertanyaan yang diajukan oleh guru sebagai bentuk feedback hasil pemikiran sesuai dengan pengalaman sehari-hari yang dijumpai atau dialami oleh siswa.

Pembelajaran model blended learning membuat siswa berkesempatan untuk bertukar pendapat atau ide yang mereka miliki. Dengan sumbangan pendapat dari peserta didik lainnya dan bimbingan dari peneliti, dapat menambah pengetahuan siswa. Hal ini sesuai dengan teori Vygotsky yang menyatakan bahwa "memberikan dukungan dan bantuan kepada peserta didik yang sedang pada awal belajar kemudian sedikit demi sedikit mengurangi dukungan atau bantuan tersebut setelah peserta didik mampu memecahkan problem dari tugas yang dihadapi" (Suprijono, 2013). Sedangkan, pada pembelajaran yang menggunakan model pembelajaran konvensional, siswa menjadi pasif dan hanya peneliti yang memberikan pengetahuan hal ini, menyebabkan 
siswa tidak mendapatkan pembelajaran yang bermakna dan jenuh dalam belajar.

Hal ini juga didukung dari beberapa penelitian yang menunjukkan terdapat pengaruh penerapan blended learning. Penelitian yang dilakukan Wahyunita \& Subroto $(2021$, p. 1017) bahwa penggunaan model pembelajaran blended learning berpengaruh terhadap kemampuan berpikir kritis siswa. Denny, et al., (2020) menunjukkan adanya peningkatan kemampuan berpikir kritis siswa setelah diberikan perlakuan yaitu dengan menggunakan model blended learning. Nilai N-Gain membuktikan peningkatan besar dalam kelas eksperimen yaitu 0.60 pada kategori sedang dan 0.23 pada kategori rendah pada kelas kontrol.

Untuk membangun lingkungan yang kolaboratif dapat digunakan fitur yang tersedia dalam aplikasi Telegram antara lain Replay, Mention, dan Hastag (Qamar, 2018). Aplikasi Telegram dapat digunakan dan diakses dengan mudah sehingga pembelajaran online tidak hanya sebagai sarana untuk memberikan tugas dan materi tambahan tetapi siswa juga dapat berdiskusi untuk menunjang pembelajaran tatap muka sehingga lebih berkualitas. Dengan demikian peserta didik dapat merasakan pengalaman baru melalui pembelajaran dan menentukan cara sendiri dalam belajar dengan menggunakan telegram. Berdasarkan jurnal Qamar dan Selamet Riyadi dengan judul Efektivitas Blended Learning menggunakan Aplikasi Telegram menunjukkan bahwa partisipan sesi online lebih aktif dari sesi offline

Dengan memberikan latihan berpikir kritis dalam pembelajaran IPS maka diharapkan peserta didik dapat menggunakan kemampuan berpikir kritis untuk menghadapi konteks kehidupannya yang lebih luas. Untuk itulah, guru perlu melakukan proses pembelajaran yang melibatkan peningkatan kemampuan berpikir peserta didik. Menurut Anggraeni, et al., (2019) bahwa keuntungan pelaksanaan dari pelaksanaan model blended learning adalah memungkinkan siswa unuk dapat belajar dimana saja dan kapan saja. Siswa dapat mendalami materi yang sedang dipelajari secara mandiri. Selain itu juga, blended learning ini juga dapat meningkatkan kemampuan berpikir kritis siswa. Hal ini terlihat dair kemampuan berpikir kritis siswa pada kelas yang diajarkan dengan blended learning yang memiliki nilai rata-rata posttest lebih tinggi dibandingkan dengan siswa yang diajarkan dengan metode konvensional.

Hasil belajar adalah kemampuan yang dimiliki siswa sebelum dan setelah proses pembelajaran. Hasil belajar siswa (dalam aspek kognitif) diperoleh dari tes. Tes hasil belajar berupa soal uraian dengan materi peristiwa seputar proklamasi kemerdekaan Indonesia. Tes dilakukan dua kali berupa pretest dan posttest. Dalam soal pretest bertujuan untuk mengetahui kondisi siswa sebelum diberikan perlakuan. Sedangkan posttest bertujuan untuk mengukur pemahaman dan hasil belajar siswa setelah diberikan perlakuan.

Hasil penelitian ini sejalan dengan penelitian yang dilakukan oleh Kantun \& Siswandini (2015) bahwa hasil belajar siswa setelah implementasi blended learning mengalami peningkatan, rata-rata persentase skor adalah 68.73 pada siklus I dan 75.04 pada siklus II. Penelitian lain dilakukan oleh Manggabarani, et al., (2016, p. 83) bahwa model blended learning berpengaruh terhadap motivasi dan hasil belajar siswa, hal ini dibuktikan dengan nilai $t_{\text {hitung }}>t_{\text {tabel }}=4.14>1.67$. Penelitian Munzadi (2018, p. 125) menyatakan bahwa hasil belajar siswa antara kelas yang diberikan perlakuan menggunakan model Blended Learning berbasis Rotation Model dengan kelas kontrol yang tidak diberikan perlakuan. Hasil belajar di kelas eksperimen lebih tinggi dari kelas kontrol secara meyakinkan dengan nilai thitung lebih besar dibandingkan nilai $t_{\text {tabel }}$ yaitu $3.8419>1.674$ pada taraf signifikansi 5\%.

Model Blended Learning memiliki kelebihan, diantaranya: 1) pembelajaran berlangsung secara otonom dan tradisional yang keduanya mempunyai kelebihan dan saling mengisi; 2) pembelajaran lebih berhasil dan berdaya guna; 3) Menunjukkan peningkatan ketersediaan; 4) siswa dapat menggunakan bahan ajar yang tersedia di web untuk mempelajari sendiri bahan ajar; 5) Siswa dapat bertukar pikiran dengan pendidik ataupun siswa lain diluar pembelajaran langsung; 6) pendidik dapat melakukan pengawasan dengan baik aktivitas 
pembelajaran yang dilaksanakan oleh siswa di luar jam pembelajaran langsung

Bentuk paling sederhana dari blended learning menurut Garrison dan Kanuka (2004) adalah perpaduan antara aktivitas kelas fisik dan aktivitas belajar yang didukung oleh teknologi daring, dan kemudian berkembang lebih lanjut dalam integrasi aktivitas pembelajaran, peserta didik, dan pendidik. Selain itu, salah satu manfaat dari model blended learning dalam proses memfasilitasi pembelajaran online maupun yang berbasis kelas, penghubung pembelajaran jarak jauh, serta penerapannya dalam pembelajaran kolaborasi online (Ansori, 2018). Penerapan model blended learning dalam penelitian ini dipadukan dengan aplikasi telegram.

Hasil belajar dapat tercapai apabila guru dalam menyampaikan pelajaran tidak menjadikan siswa hanya sebagai objek belajar, tetapi siswa dijadikan sebagai subyek, sehingga siswa bisa terlibat langsung dalam proses pembelajaran. Selain itu juga, guru tidak hanya menggunakan model pembelajaran yang monoton, tetapi guru harus bisa mengembangkan model pembelajaran yang bervariasi dan menyenangkan agar siswa senang dalam mengikuti pelajaran dan dapat meningkatkan hasil belajar siswa. Pelaksanaan pembelajaran menggunakan model blended learning dengan aplikasi Telegram dalam penelitian inidengan komposisi 50\% tatap muka, $25 \%$ pembelajaran secara mandiri, $25 \%$ pembelajaran dengan menggunakan web (Sudarman, 2018).

Suprijono (2009:5) berpendapat bahwa hasil belajar adalah pola-pola perbuatan, nilainilai, pengertian-pengertian, sikap-sikap, apresiasi dan keterampilan. Sedangkan menurut Sudjana (2014:2) hasil belajar adalah kemampuankemampuan yang dimiliki siswa setelah ia menerima pengalaman belajarnya. Pengalaman belajar mencakup segala aktifitas yang diikuti oleh siswa dari mulai masuk kelas hingga pembelajaran telah selesai. Untuk menyederhanakan makna yang tedapat pada dalam hasil belajar yang dilakukan peneliti hanya dalam ranah kognitifnya saja. Keberhasilan belajar dalam IPS dapat dicapai jika dalam prosesnya siswa yang membentuk dan merasakan sendiri pengetahuan itu yang didapatnya melalui berbagai bentuk interaksi.

Hal ini juga sesuai dengan teori kognitif yang dikembangkan oleh Piaget (Thobroni, 2015:79) bahwa belajar adalah perubahan persepsi dan pemahaman. Belajar tidak selalu berbentuk perubahan tingkah laku yang bisa diamati. Asumsi dasar dari teori ini adalah setiap orang telah mempunyai pengalaman dan pengetahuan dalam dirinya. Berdasarkan teori ini, proses belajar lebih baik jika materi pelajaran yang baru, beradaptasi dengan struktur kognitif yang telah dimiliki oleh siswa. Perkembangan anak juga tergantung pada interaksi lingkungan masyarakat dan keluarga.

Sesuai dengan teori Piaget, siswa kelas IV sekolah dasar berada pada tahap operasional konkrit, dalam hal ini siswa dapat mengindikasikan pemikiran logisnya. Siswa juga dapat membuat kesimpulan dari sesuatu pada situasi nyata atau dengan menggunakan benda konkrit. Kemajuan siswa dalam periode ini adalah siswa sudah mempunyai kemampuan untuk berpikir rasional, karena itu model pembelajaran blended learning dapat diterapkan pada siswa kelas IV Sekolah Dasar. Untuk itulah, proses pembelajaran harus melibatkan partisipasi siswa. Anak harus dilibatkan secara aktif dalam kegiatan pembelajaran bersama teman sebayanya maupun guru. Selain itu, tujuan utama dari model pembelajaran blended learning adalah menciptakan kemandirian, keberlanjutan pembelajaran sepanjang hayat dan perkembangan peserta didik sesuai dengan karakteristiknya.

\section{SIMPULAN DAN REKOMENDASI}

Berdasarkan kajian teori dan hasil penelitian yang dipaparkan penulis, dapat disimpulkan bahwa model blended learning dengan aplikasi telegram berpengaruh terhadap kemampuan berpikir kritis dan hasil belajar siswa pada mata pelajaran IPS materi peristiwa seputar proklamasi Kelas V SDN Semambung Sidoarjo. Model blended learning dengan aplikasi telegram dilaksanakan secara online maupun offline, hal ini juga sebagai bentuk solusi karena adanya pandemi covid-19 sehingga proses pembelajaran tetap dapat terlaksana . 
Guru sebaiknya memperhatikan karakteristik siswa dan selalu melibatkan siswa dalam proses pembelajaran yang berhubungan dengan materi yang akan disampaikan agar siswa dapat lebih semangat dan menunjuang kemampuan berpikir kritis siswa. Model blended learning dilaksanakan secara daring sehingga memudahkan siswa dan orang tua agar pembelajaran tetap berjalan meskipun tanpa tatap muka.

\section{DAFTAR PUSTAKA}

Ahmatika, D. (2017). Peningkatan Kemampuan Berpikir Kritis Siswa Dengan Pendekatan Inquiry/Discovery. Jurnal Euclid, 3 (1), 377-525.

Anggraini, A. D., Wonorahardjo, S., \& Utomo, Y. (2016). Efektivitas Pembelajaran Blended Learning Berbasis Community on Inquiry (CoI) ditinjau dari Belajar Kognitif Mahasiswa pada Materi Kromatografi. Prosiding Seminar Nasional II, 1038- 1046

Anggraeni, A., Supriana, E., \& Hidayat, A. (2019). Pengaruh Blended Learning terhadap Kemampuan Berpikir Kritis Siswa SMA pada Materi Suhu dan Kalor. Jurnal Pendidikan: Teori, Penelitian dan Pengembangan, 4 (6), 758-763.

Ansori, M. (2018). Desain dan Evaluasi Pembelajaran Blended Learning Berbasis Whatsapp Group. Jurnal Study Ilmu dan Manajemen Pendidikan Islam, $1 \quad$ (1), 120-137. DOI: https://doi.org/10.29062/dirasah.v1i1.56

Ardianti, S., Sulisworo, D., Pramudya, Y., Raharjo, W. (2020). The Impact of the Use of STEM Education Approach on the Blended Learning to Improve Student's Critical Thinking Skills. Universal Journal of Educational Research, 8 (3B), 24-32.

DOI: https://doi.org/10.13189/ujer.2020.0815 03

Arikunto, S. (2013). Prosedur Penelitian: Suatu Pendekatan Praktek. Jakarta: Rineka Cipta.

Baety, D. N., \& Munandar, D. R. (2021). Analasis
Efektifitas Pembelajaran Daring Dalam Menghadapi Wabah Pandemi Covid-19. Edukatif: Jurnal Ilmu Pendidikan, 3 (3), 880-889.

DOI: https://doi.org/https://doi.org/10.31004/e dukatif.v3i3.476

Bonk, C. J., \& Graham, C. R. (2006). Handbook of Blended Learning: Global Perspective, Local Design. Cheicester: John Wiley \& Sons Inc

Cahyono, B. (2017). Analisis Ketrampilan Berfikir Kritis Dalam Memecahkan Masalah Ditinjau Perbedaan Gender. Aksioma, 8 (1), $50 . \quad$ DOI: https://doi.org/10.26877/aks.v8i1.1510

Chowdhury, F. (2020). Blended learning: how to flip the classroom at HEIs in Bangladesh?. Journal of Research in Innovative Teaching \& Learning, 13 (2), 228-242. DOI:

https://doi.org/10.1108/JRIT-12-2018$\underline{0030}$

Denny, Y. R., Utami, I. S., Rohanah, S., \& Muliyati, D. (2020). The Development of Blended Learning Model using Edmodo to Train Student Critical Thinking Skills on Impulse-Momentum Topic. Jurnal Penelitian dan Pengembangan Pendidikan Fisika, 6 (1), 113-120.

Dwiyogo, W. D. (2018). Pembelajaran Berbasis Blended Learning. Depok: Raja Grafindo

Ennis, R. H. (1985). Critical Thinking. New Jersey: Prentice-Hall Inc

Ferra, F. R. (2019). Google Classroom pada Metode Blended Learning terhadap Kemampuan Berpikir Kritis dan Hasil Belajar Siswa Kelas VII SMP XIN Zhong Mata Pelajaran IPS. Makalah Komprehensif Program Pascasarjana. Surabaya: Universitas Negeri Surabaya.

Fisher, A. (2017). Berpikir Kritis Sebuah Pengantar. Jakarta: Erlangga.

Garrison, R., \& Kanuka, H. (2004). Blended Learning: Uncovering its Transformative Potential in Higher Education. Internet and Higher Education Journal, 7 (2), 95105.

Hestiningsih, N., \& Sugiharsono, S. (2015). 
Peningkatan Kemampuan Berpikir Kritis Peserta Didik Pembelajaran Problem Solving Berbantuan Media Informasi. Harmoni Sosial: Jurnal Pendidikan IPS, $2 \quad$ (1), 71-86. DOI: https://doi.org/10.21831/hsjpi.v2i 1.4619

Husamah. (2013). Pembelajaran Bauran (Blended Learning). Jakarta: Hasil Pustaka

Kantun, S., \& Siswandini, R. (2015). Implementasi Blended Learning Untuk Meningkatkan Kreativitas Dan Hasil Belajar Pada Mata Pelajaran Ekonomi Peserta Didik Kelas XI IPS-2 Sman 5 Jember Semester Gasal Tahun 2015/2016. JPE: Jurnal Pendidikan Ekonomi, 9 (2), 141-152.

Khoiroh, N., Munoto., \& Anifah, L. (2017). Pengaruh Model Pembelajaran Blended Learning dan Motivasi Belajar Terhadap Hasil Belajar Siswa. Jurnal Penelitian Ilmu Pendidikan, 10 (2), 97-110.

Lakovos, T. (2011). Critical and Creative Thinking in the English Language Classroom. International Journal of Humanities and Social Science, 1 (8), 65-80

Larsson, K. (2017). Understanding and teaching critical thinking-A new approach. International Journal of Educational Research, 84, 32-42

Maisaroh., \& Roestrieningsih. (2010). Peningkatan Hasil Belajar Siswa Dengan Menggunakan Metode Pembelajaran Active Learning Tipe Quiz Team Pada Mata Pelajaran Keterampilan Dasar Komunikasi Di SMK Negeri 1. Jurnal Ekonomi dan Pendidikan, 8 (2), 157-172. https://journal.uny.ac.id/index.php/jep/ar ticle/download/571/427

Manggabarani, A. F., Sugiarti, \& Masri, M. (2016). Pengaruh Model Pembelajaran Blended Learning Terhadap Motivasi Dan Hasil Belajar Siswa Kelas X SMA Negeri 1 Pitumpanua Kab. Wajo (Studi Pada Materi Pokok Sistem Periodik Unsur). Jurnal Chemical, 17 (2), 83-93.

Munzadi, M. (2018). Pengaruh Blended Learning Berbasis Rotation Model Terhadap
Motivasi dan Hasil Belajar Geografi Siswa MA Matholiul Anwar Lamongan. Jurnal Pendidikan Geografi Undiksha, 6 (3), 125-132.

Nasution. (2015). Kajian Pembelajaran IPS di Sekolah. Surabaya: Unesa University Press

Ningsih, W. S. A., Suana, W., Maharta, N. (2018). Pengaruh Penerapan Blended Learning Berbasis Schoology Terhadap Kemampuan Berpikir Kritis Siswa. Konstan (Jurnal Fisika dan Pendidikan Fisika), 3 (2), 85-93. DOI: https://doi.org/10.20414/konstan.v3i2.16

Priyatno, D. (2014). SPSS22: Pengolahan Data Terpraktis. Yogyakarta: CV. Andi Offset

Putra, R. A., \& Hanggara, A. (2018). Pengaruh Pendekatan Saintifik Berorientasi Higher Order Thinking Skills (HOTS) Terhadap Pemahaman Belajar Siswa. Equilibirium: Jurnal Pendidikan dan Ekonomi, 15(2), 44-50. DOI: https://doi.org/10.25134/equi.v15i02.16 18.

Qamar, K., \& Riyadi, S. (2018). Efektivitas Blended Learning Menggunakan Aplikasi Telegram. At-Tajdid: Jurnal Ilmu Tarbiyah, 7 (1), 1-15. Diunduh dari http://ejournal.inismupacitan.ac.id/index .php/tajdid/article/view/121

Riyanto, Y. (2007). Metodologi penelitian pendidikan kualitatif dan kuantitatif. Surabaya: Unesa University Press.

Rusman., Kurniawan, Deni., \& Riyana, Cepi. (2013). Pembelajaran Berbasis Teknologi Informasi dan Komunikasi (Mengembangkan Profesionalitas Guru). Jakarta: PT. Raja Grafindo

Sardjiwo. (2014). Pendidikan IPS di SD. Jakarta: Universitas terbuka

Siregar, S. (2014). Metode Penelitian Kuantiatif. Jakarta: Kencana Prenada.

Solikh, M. N., Sulisworo, D., \& Maruto, G. (2018). Pengaruh model pembelajaran blended learning berbantuan google classroom terhadap kemampuan berpikir kritis ditinjau dari self esteem dan kecerdasan 
intelektual. Jurnal Materi dan Pembelajaran Fisika, 2 (8), 27-32.

Suana, W, Maharta, N., Nyeneng, I. D. P., \& Wahyuni, S. (2017). Design and Implementation of Schoology Based Blended Learning Media For Basic Physic I Course. Journal Pendidikan IPA Indonesia, 6 (1), 170-178. DOI: https://doi.org/10.15294/jpii.v6i1.8648.

Suana, W., Raviany, M., \& Sesunan, F. (2019). Blended Learning Berbantuan Whatsapp: Pengaruhnya Terhadap Kemampuan Berpikir Kritis Dan Kemampuan Pemecahan Masalah. Gravity, 5 (2), 37-45.

Sudarman. (2018). Pengaruh Strategi Pembelajaran Blended Learning Terhadap Perolehan Belajar Konsep dan prosedur Pada Mahasiswa Yang Memiliki Self- Regulated Learning Berbeda. Jurnal Pendidikan dan Pembelajaran, 21 (1), 107-117

Sudjana N. (2007). Media Pembelajaran. Bandung: Sinar Baru Algesindo

Sudjana, N. (2014). Penelitian Hasil Proses Belajar Mengajar. Bandung: Remaja Rosdakarya.

Sugiyono. (2016). Metode Penelitian Pendidikan Pendekatan Kualitatif, Kuantitatif, dan R $\& D$. Bandung: Alfabeta.

Suhartono. (2016). Menggagas Pendekatan Blended Learning di Sekolah Dasar. Prosiding Temu Ilmiah Nasional Guru (Ting) VIII, 544-555. Diunduh dari http://repository.ut.ac.id/6550/

Sulisworo, D., Ummah, R., Nursolikh, M., \& Rahardjo, W.(2020). The Analysis of the critical thinking skill between Blended Learning Implementation: google classroom and schoology. Universal Journal of Education, 8 (3B), 33-40. DOI: $\quad$ https://doi.org/10.13189 ujer.2020.081504.

Sundayana, R. (2014). Statistika Penelitian Pendidikan. Bandung: Penerbit Alfabeta.

Suprijono, A. (2013). Cooperative Learning Teori dan Aplikasi Paikem. Yogyakarta: Pustaka Belajar.
Tarunasena. (2012). Blended Learning Model Implementation to Improve Critical Thinking Skill in History Learning. Historia: International Journal of History Education, 13 (2), 153-176.

Thobroni, M. (2015). Belajar dan Pembelajaran: Teori dan Praktek. Yogyakarta: ArrRuzz Media.

Tio, A. S. (2019). Kelebihan Telegram dan Kekurangannya Sebagai Aplikasi Perpesanan Gratis. Diunduh dari https://calonpengangguran.com/2019/09 /12/kelebihan-Telegram/

Trianto. (2009). Mendesain Pembelajaran Inovatif Progresif. Jakarta: Kencana

Wahyunita, I., \& Subroto, W. T. (2021). Efektivitas Model Pembelajaran Blended Learning dengan Pendekatan STEM Dalam Upaya Meningkatkan Kemampuan Berfikir Kritis Peserta Didik. Edukatif: Jurnal Ilmu Pendidikan, 3 (3), 1010-1021.

Wicaksono, V. D., \& Rahmadyanti, P. (2017). Pembelajaran Blended Learning Melalui Google Classroom di Sekolah Dasar. Prosiding Seminar Nasional dan Call for Papers Pendidikan 2017 (PGSD UMS \& HDPGSDI Wilayah Jawa), 513-521.

Widodo, Sigit. (2016). Pengembangan Keterampilan Berpikir Kritis Peserta Didik Dengan Menggunakan Model Pembelajaran Berbasis Masalah (Problem Based Learning) Melalui IsuIsuSosial Ekonomi Pasca Penggenangan Waduk Jatigede Dalam Pembelajaran IPS Di SMPN 2 Wado Kabupaten Sumedang Kelas VIII C. International Journal Pedagogi of Social Studies, I (2),

1-14. DOI: https://doi.org/10.17509/ijposs.v1i2.471 2

Yapici, I. U., \& Akbayin, H. (2012). The Effect of Blended Learning Model in High School Students' Biology Achievement and on Their Attitudes Towards the Internet. The Turkish Online Journal of Educational Technology 11, 228-237

Yuadarma, Isti. (2017). Upaya Meningkatkan 
Jurnal PAJAR (Pendidikan dan Pengajaran)

Volume 5 Nomor 5 September 2021 | ISSN Cetak : 2580 - 8435 | ISSN Online : 2614 - 1337

DOI : http://dx.doi.org/10.33578/pjr.v5i5.8463

Kemampuan Berpikir Kritis

Menggunakan Metode Studi Kasus pada

Pembelajaran IPS Kelas IV SD Krapyak

Wetan Sewon Bantul. Skripsi.

Yogyakarta: Universitas Negeri

Yogyakarta. 